\title{
Uji Eksperimental Perbandingan Komposisi Sekam Padi dengan Batubara sebagai Bahan Bakar
}

\author{
Rio Erlangga Maharja ${ }^{1 *}$, Syahrul Mubarak ${ }^{2}$, Muhammad Anshar $^{3}$ dan Jumadi Tangko ${ }^{4}$ \\ 1,2,3,4 Jurusan Teknik Mesin, Politeknik Negeri Ujung Pandang, Makassar 90245, Indonesia \\ *riomaharja@gmail.com
}

\begin{abstract}
The increase in coal consumption in Indonesia has increased compared to previous years. Studies show that coal consumption increases relatively from year to year. Coal consumption must be balanced with the provision of renewable alternative energy. Utilization of alternative energy that can be used is rice husk biomass because it is supported by the relatively high production of rice husks, namely 9,808 MW. This study aims to test an experimental comparison of the composition of rice husks with coal as fuel. This study used a mixture of rice husks and coal using proximate and ultimate analysis. The analysis tested was the energy potential of rice husk, moisture content, ash content, volatile matter, bonded carbon, and heating value. The ratio of rice husks and coal which is applied in this study is 10\%:90\%, 30\%:70\%, 50\%:50\%, 70\%:30\%, 90\%:10\% In addition, research was also carried out on 100\% of rice husks and rice husks. 100\% coal. The process of filtering and mixing the composition of materials is carried out at the Mechanical Engineering Energy Laboratory and the Civil Engineering Laboratory of Ujung Pandang State Polytechnic. The results showed that various variations in the mixture of rice husks and coal, the calorific value obtained for 10\%:90\% was 16.05 MJ/kg, 30\%:70 was 15.16 $\mathrm{MJ} / \mathrm{kg}$, 50\%:50\% was $14.89 \mathrm{MJ} / \mathrm{kg}, 70 \%: 30 \%$ is $13.90 \mathrm{MJ} / \mathrm{kg}, 90 \%: 10 \%$ is $13.25 \mathrm{MJ} / \mathrm{kg}$, where the highest heating value is obtained in a mixture containing $90 \%$ coal powder composition with a heating value of 16.05 $M J / k g$.
\end{abstract}

Keywords: rice husk; coal;analysis proxinate and ultimate

\begin{abstract}
Abstrak: Peningkatan konsumsi batubara di Indonesia mengalami peningkatan dibandingkan beberapa tahun sebelumnya. Studi menunjukkan bahwa konsumsi batubara relatif meningkat dari tahun ke tahun. Konsumsi batubara harus diimbangi dengan penyediaan energi alternatif yang dapat diperbaharui. Pemanfaatan energi alternatif yang dapat digunakan yaitu biomassa sekam padi karena didukung oleh produksi sekam padi yang tergolong cukup tinggi yaitu 9.808 MW. Penelitian ini bertujuan untuk uji eksperimental perbandingan komposisi sekam Padi dengan batubara sebagai bahan bakar. Penelitian ini menggunakan campuran sekam padi dan batubara menggunakan analisis proximate dan ultimate. Adapun analisa yangdiuji adalah potensi energi sekam padi, kadar air, kadar abu, volatile matter, karbon terikat, dan nilai kalor. Perbandingan sekam padi dan batubara yang diterapkan dalam penelitian ini adalah 10\%:90\%, 30\%:70, 50\%:50\%, 70\%:30\%, 90\%:10\% Selain itu dilakukan juga penelitian terhadap $100 \%$ sekam padi dan $100 \%$ batubara. Proses penyaringan dan pencampuran komposisi bahan dilakukan di Laboratorium Energi Teknik Mesin dan Laboratorium Teknik Sipil Politeknik Negeri Ujung Pandang. Hasil penelitian menunjukkan bahwa berbagai variasi campuran sekam padi dan batubara, nilai kalor yang diperoleh untuk 10\%:90\% adalah $16.05 \mathrm{MJ} / \mathrm{kg}, 30 \%: 70$ adalah $15.16 \mathrm{MJ} / \mathrm{kg}, 50 \%: 50 \%$ adalah $14.89 \mathrm{MJ} / \mathrm{kg}, 70 \%: 30 \%$ adalah $13.90 \mathrm{MJ} / \mathrm{kg}, 90 \%: 10 \%$ adalah $13.25 \mathrm{MJ} / \mathrm{kg}$, dimana nilai kalor tertinggi diperoleh pada campuran yang mengandung komposisi serbuk batubara $90 \%$ dengan nilai kalor yaitu $16.05 \mathrm{MJ} / \mathrm{kg}$.
\end{abstract}

Kata kunci: sekam padi; batubara; analisis proxinate dan ultimate

\section{I.PENDAHULUAN}

Energi sangat diperlukan dalam menjalankan aktivitas perekonomian Indonesia, baik untuk kebutuhan konsumsi maupun aktivitas produksi berbagai sektor industri. Energi tersebut diperoleh dari sumber daya energi yang bersifat unrenewable resources dan renewable resources. Akan tetapi, perolehan sumber daya energi cenderung difokuskan pada energi fosil yang bersifat unrenewable resources [1]. Salah satu energi fosil yang bersifat unrenewable resource adalah batubara yang banyak digunakan sebagai bahan bakar utama dari sistem pembangkit energi tenaga uap.

Berbagai studi tersebut menunjukkan bahwa konsumsi batubara relatif meningkat dari tahun ke tahun. Konsumsi batubara yang berlebihan ini dapat mengakibatkan ketersediaan batubara semakin berkurang. Menurut [2] bahwa secara global batubara diperkirakan habis sekitar 112 tahun ke depan. 
Oleh karena itu, konsumsi batubara harus segera diimbangi dengan penyediaan energi alternatif yang dapat diperbaharui, melimpah jumlahnya, dan murah harganya sehingga terjangkau oleh masyarakat luas [3]. Dengan meningkatnya pemakaian batubara sebagai bahan bakar maka akan memberikan dampak pada lingkungan terutama kualitas udara di sekitarnya. Hal ini dikarenakan batubara termasuk bahan bakar fosil yang mengandung hidrokarbon. Hidrokarbon ini jika dibakar sempurna akan menghasilkan gas $\mathrm{CO} 2$ yang merupakan salah satu gas rumah kaca. Karbondioksida di atmosfir dapat berkurang secara alami karena terserap oleh lautan dan diserap tanaman untuk digunakan dalam proses fotosintesis, namun aktifitas manusia yang melepaskan karbondioksida ke udara jauh lebih cepat dari kemampuan alam untuk menguranginya.

Pemanfaatan energi alternatif yang dapat digunakan pada zaman ini yaitu yaitu biomassa. Biomassa adalah bahan organik yang berasal dari tanaman atau hewan, termasuk produk pertanian, kehutanan, sampah kota, dan sampah lainnya. Menurut [5] bahwa terdapat beberapa sumber energi biomassa, salah satunya adalah sekam padi. Hal ini disebabkan karena produksi sekam padi tergolong cukup tinggi yaitu 9.808 MW. Berdasarkan data Badan Pusat Statistik Nasional, produksi padi dalam kurun waktu 2011 hingga 2015 yaitu rata-rata sebesar 73.19 x 106 ton dan menghasilakan sekam sebesar 21.96 x 106. Sedangkan berdasarkan [5] produksi padi yang pada tahun 2013 mencapai 4.917 x 106 ton dan terus meningkat hingga tahun 2015 sebesar 5.29 x 106 ton sehingga sekam padi yang dihasilkan sangat berpotensi dijadikan energi alternatif untuk mengurangi pemakaian bahan bakar fosil.

Tahun 2013, Indonesia menghasilkan sekam padi yang besar yaitu $13.809 \times 106$ ton dengan potensi energi kurang lebih $53.702 \mathrm{GWh}$ dan jerami sebesar 106,31 juta ton dengan potensi energi $25 \%$ [6]. Hanya saja, pemanfaatan biomassa tersebut sebagai energi alternatif masih sangat kurang.

Menurut [7] pembakaran serentak (co-firing) biomassa dengan batubara mengurangi emisi gas rumah kaca dan polusi udara tradisional (SO2, NOx). Emisi SOx relatif berkurang akibat pembakaran serentak biomassa dengan batubara atau disebut, sebanding beban kalor biomassa, Emisi NOx dapat bertambah, berkurang atau konstan bila pembakaran serentak biomassa dengan batubara. Di lain pihak [8] mengemukakan pembakaran Biocoal atau istilah yang digunakan untuk pembakran antara bahan bakar serbuk batubara dengan sekam padi (pulverized fuel combustion reactor) menghasilkan emisi gas polusi meliputi $\mathrm{CO}, \mathrm{CO} 2, \mathrm{NOx}$, dan $\mathrm{SO} 2$ berkurang dengan bertambahnya rasio sekam padi terhadap batubara. Merujuk pada potensi tersebut maka perlu dilakukan penelitian mengenai "Uji Eksperimental Perbandingan Komposisi Sekam Padi dengan Batubara sebagai Bahan Bakar”.

\section{II.METODE PENELITIAN}

\section{A. Tempat Penelitian}

Penelitian dilakukan di Laboratorium Energi Teknik Mesin, pembuatan sampel di lakukan di Laboratorium Teknik Sipil dan pengujian sampel dilakukan di Laboratorium Pusat Penelitian dan Pengembangan Teknologi Mineral dan Batu Bara, Bandung. 
3 Rio Erlangga Maharja, Syahrul Mubarak, Muhammad Anshar, Jumadi Tangko. Uji Eksperimental Perbandingan Komposisi Sekam Padi dengan Batubara sebagai Bahan Bakar

\section{B. Prosedur Penelitian}

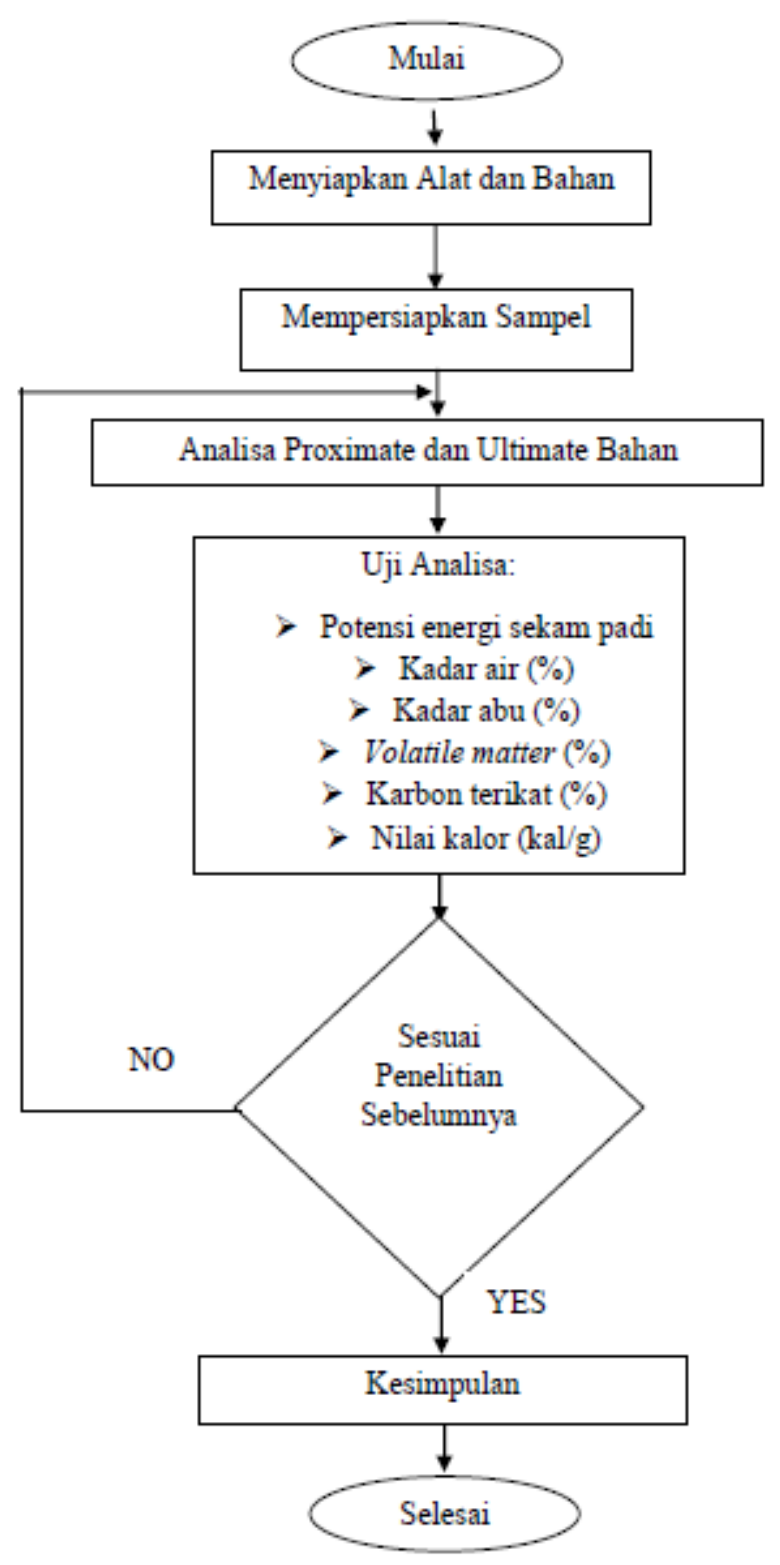

Gambar 1. .Flowchart Proses Pengambilan Data

\section{HASIL DAN PEMBAHASAN}

A. Hasil Pembuatan Sampel Batubara dan Sekam Padi

Hasil pembuatan sampel dari 7 jenis sampel adalah sebagai berikut:

a. Batubara $100 \%$

Sampel pertama ialah Batubara jenis sub bituminus yang ditumbuk dan dihaluskan kemudian ditapis menggunakan ayakan dengan ukuran 100 mesh atau jika dikonversi berukuran $0.149 \mathrm{~mm}$ dengan berat mencapai 20 gram.

b. Sekam Padi $100 \%$

Sampel yang kedua ialah Sekam Padi jenis organik dihaluskan menggunakan blender kemudian ditapis menggunakan ayakan dengan ukuran 100 mesh atau jika dikonversi berukuran $0.149 \mathrm{~mm}$ dengan berat mencapai 20 gram.

c. Sekam Padi dan Batubara (90\%:10\%)

Sampel ketiga ialah campuran antara sekam padi $90 \%$ dan batubara $10 \%$ yang telah 
dihaluskan kemudian ditapis menggunakan ayakan dengan ukuran 100 mesh atau jika dikonversi berukuran $0.149 \mathrm{~mm}$ dengan berat mencapai

d. Sekam Padi dan Batubara (70\%:30\%)

Sampel keempat ialah campuran antara sekam padi $70 \%$ dan batubara $30 \%$ yang telah dihaluskan kemudian ditapis menggunakan ayakan dengan ukuran 100 mesh atau jika dikonversi berukuran $0.149 \mathrm{~mm}$ dengan berat mencapai 20 gram.

e.Sekam Padi dan Batubara (50\%:50\%)

Sampel kelima ialah campuran antara sekam padi 50\% dan batubara 50\% yang telah dihaluskan kemudian ditapis menggunakan ayakan dengan ukuran 100 mesh atau jika dikonversi berukuran $0.149 \mathrm{~mm}$ dengan berat mencapai 20 gram.

f. Sekam Padi dan Batubara (30\%:70\%)

Sampel ketujuh ialah campuran antara sekam padi 30\% dan batubara $70 \%$ yang telah dihaluskan kemudian ditapis menggunakan ayakan dengan ukuran 100 mesh atau jika dikonversi berukuran $0.149 \mathrm{~mm}$ dengan berat mencapai 20 gram.

g. Sekam Padi dan Batubara (10\%:90\%)

Sampel keenam ialah campuran antara sekam padi 10\% dan batubara 90\% yang telah dihaluskan kemudian ditapis menggunakan ayakan dengan ukuran 100 mesh atau jika dikonversi berukuran $0.149 \mathrm{~mm}$ dengan berat mencapai 20 gram.

\section{B. Perhitungan Potensi Energi dari Sekam Padi}

Hasil dari perhitungan potensi energi sekam padi dapat dilihat pada table di bawah ini:

Tabel 1. Hasil Perhitungan Potensi Energi Sekam Padi Indonesia pada 2012-2016

\begin{tabular}{cccccccc}
\hline No & Tahun & $\begin{array}{c}\text { PP } \\
\left(\mathrm{x} 10^{3} \mathrm{Ton}\right)\end{array}$ & $\begin{array}{c}\mathrm{SP} \\
\left(\mathrm{x} 10^{3} \mathrm{Ton}\right)\end{array}$ & $\begin{array}{c}\mathrm{Eqcoal}\left(\mathrm{x} 10^{3}\right. \\
\mathrm{Ton})\end{array}$ & $\mathrm{EP}_{\mathrm{RH}}(\mathrm{TJ})$ & $\begin{array}{c}\mathrm{EE}_{\mathrm{RH}} \\
(\mathrm{GWh})\end{array}$ & $\begin{array}{c}\mathrm{EC}_{\mathrm{RH}} \\
(\mathrm{GW})\end{array}$ \\
\hline 1 & 2012 & 69.06 & 13.812 & 11.22 & 179.56 & 49.88 & 5.69 \\
2 & 2013 & 71.28 & 14.256 & 11.58 & 185.33 & 51.48 & 5.88 \\
3 & 2014 & 70.85 & 14.17 & 11.51 & 184.21 & 51.17 & 5.84 \\
4 & 2015 & 75.4 & 15.08 & 12.25 & 196.04 & 54.46 & 6.22 \\
5 & 2016 & 79.36 & 15.872 & 12.90 & 206.34 & 57.32 & 6.54 \\
\hline \multicolumn{2}{r}{ Rata-rata } & 73.19 & 14.638 & 11.90 & 190.29 & 52.86 & 6.03 \\
\hline
\end{tabular}

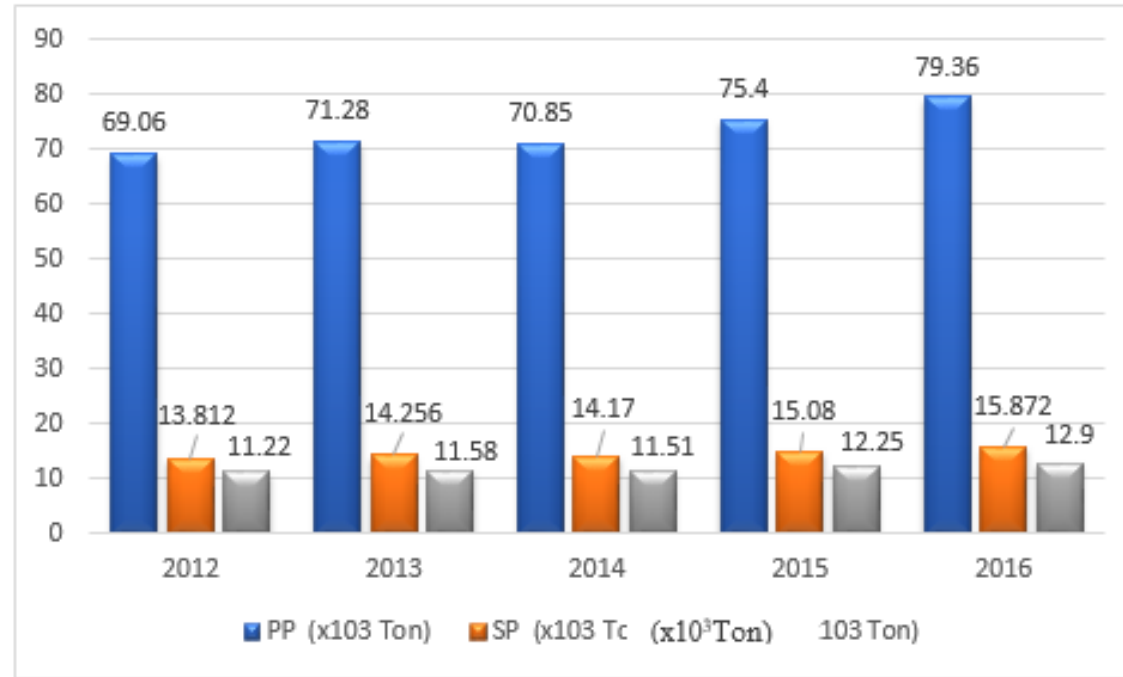

Gambar 2. Grafik Perbandingan Produksi Padi, Sekam Padi, dan Eqcoal Indonesia 


\section{Rio Erlangga Maharja, Syahrul Mubarak, Muhammad Anshar, Jumadi Tangko. Uji Eksperimental}

Perbandingan Komposisi Sekam Padi dengan Batubara sebagai Bahan Bakar

Berdasarkan tabel 1 dan grafik 2 di atas, bahwa selama kurun waktu 2012-2016, bahwa produksi padi meningkat secara signifikan setiap tahunnya. Kecuali pada tahun 2014 menurun tetapi kemudian meningkat kembali pada tahun 2015. Secara umum potensi sekam padi dan parameter lainnya meningkat setiap tahunnya. Potensi energi sekam padi untuk dijadikan sebagai suatu pembangkit memungkinkan, karena dalam kurun 5 tahun tersebut nilai rata-rata sekam padi yaitu 14.638 x 103 Ton atau sama dengan $11.90 \times 103$ Ton untuk batubara, dimana dapat menghasilkan potensi energi listrik sebesar 52.86 GWh dan daya listrik sekitar $6.03 \mathrm{GW}$.

Tabel 2. Hasil Perhitungan Potensi Energi Sekam Padi Sulawesi Selatan pada 2012-2016

\begin{tabular}{|c|c|c|c|c|c|c|c|}
\hline No & Tahun & $\begin{array}{c}\text { PP } \\
\left(\mathrm{x} 10^{3} \text { Ton }\right)\end{array}$ & $\begin{array}{c}\mathrm{RH} \\
\left(\mathrm{x} 10^{3} \text { Ton }\right)\end{array}$ & $\begin{array}{c}\text { Eqcoal } \\
\text { (x10 } 10^{3} \text { Ton) }\end{array}$ & $\begin{array}{l}\mathrm{EP}_{\mathrm{RH}} \\
(\mathrm{TJ})\end{array}$ & $\begin{array}{c}\mathrm{EE}_{\mathrm{RH}} \\
(\mathrm{GWh})\end{array}$ & $\begin{array}{l}\mathrm{EC}_{\mathrm{RH}} \\
(\mathrm{GW})\end{array}$ \\
\hline 1 & 2012 & 49.41 & 9.88 & 8.03 & 128.47 & 35.69 & 4.074 \\
\hline 2 & 2013 & 49.17 & 9.83 & 7.99 & 127.84 & 35.51 & 4.054 \\
\hline 3 & 2014 & 52.74 & 10.55 & 8.57 & 137.11 & 38.09 & 4.348 \\
\hline 4 & 2015 & 52.92 & 10.58 & 8.60 & 137.60 & 38.22 & 4.363 \\
\hline 5 & 2016 & 57.27 & 11.45 & 9.31 & 148.90 & 41.36 & 4.722 \\
\hline \multicolumn{2}{|c|}{ Rata-rata } & 52.30 & 10.46 & 8.50 & 135.99 & 37.77 & 4.312 \\
\hline
\end{tabular}

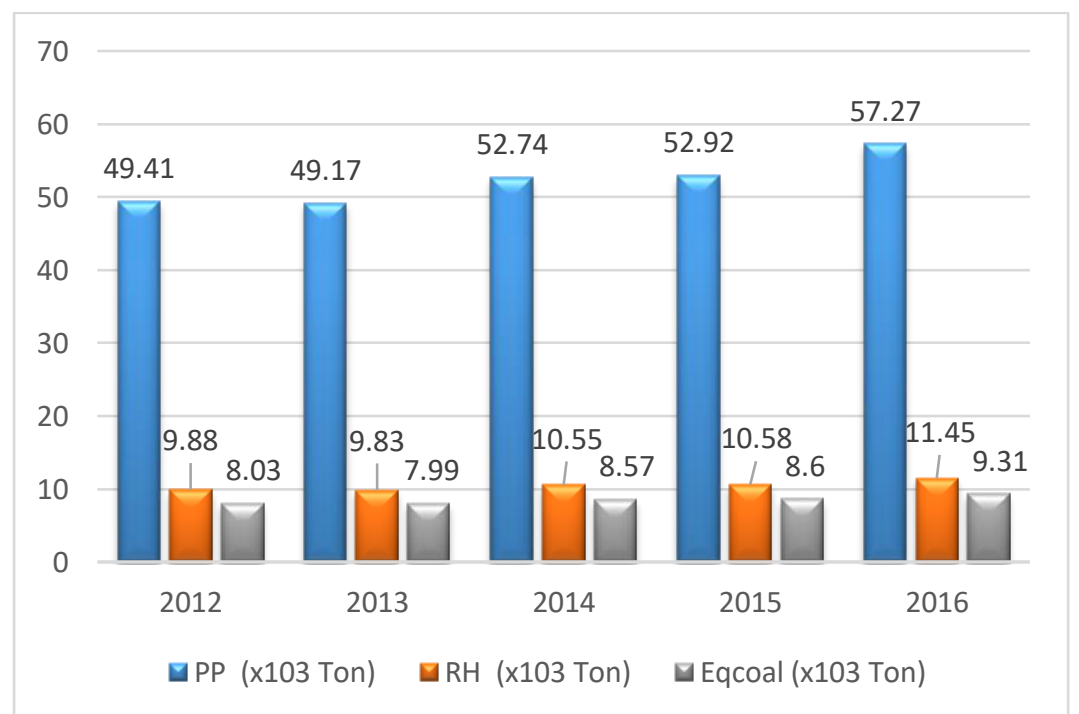

Gambar 3. Grafik Perbandingan Produksi Padi, Sekam Padi, dan Eqcoal Sulawesi Selatan

Berdasarkan tabel 2 dan grafik 3 di atas, bahwa selama kurun waktu 2012-2016, bahwa produksi padi Sulawesi Selatan meningkat secara signifikan setiap tahunnya, kecuali pada tahun 2013 menurun tetapi kemudian meningkat kembali pada tahun 2014. Secara umum potensi sekam padi dan parameter lainnya meningkat setiap tahunnya. Potensi energi sekam padi untuk dijadikan sebagai suatu pembangkit memungkinkan, karena dalam kurun 5 tahun tersebut nilai rata-rata sekam padi yaitu $10.46 \times 10^{3}$ ton atau sama dengan $8.50 \times 10^{3}$ ton untuk batubara, dimana dapat menghasilkan potensi energi listrik sebesar $37.77 \mathrm{GWh}$ dan daya listrik sekitar $4.312 \mathrm{GW}$. 
Tabel 3. Data hasil pengujian proximate dan nilai kalor

\begin{tabular}{cccccccc}
\hline NO & $\begin{array}{c}\text { Komposisi } \\
\text { Campuran } \\
(\%)\end{array}$ & MC $(\%)$ & $\begin{array}{c}\text { Ash } \\
(\%)\end{array}$ & $\begin{array}{c}\text { VM } \\
(\%)\end{array}$ & $\begin{array}{c}\text { Kadar FC } \\
(\%)\end{array}$ & $\begin{array}{c}\text { HCV } \\
(\mathrm{MJ} / \mathrm{kg})\end{array}$ & $\begin{array}{c}\text { LCV } \\
(\mathrm{MJ} / \mathrm{kg})\end{array}$ \\
\hline 1 & BB 100 & 30,72 & 7,74 & 34,68 & 26,68 & 16,2 & 15,09 \\
2 & BS 90 & 27,24 & 9,16 & 36,44 & 27,16 & 16,05 & 14,98 \\
3 & BS 70 & 23,15 & 12,2 & 40,79 & 23,86 & 15,16 & 14,30 \\
4 & BS 50 & 20,42 & 14,58 & 45,1 & 19,9 & 14,89 & 13,39 \\
5 & BS 30 & 16,04 & 17,26 & 50,1 & 16,6 & 13,9 & 12,70 \\
6 & BS 10 & 12,66 & 20,08 & 54,28 & 12,6 & 13,25 & 11,97 \\
7 & SP 100 & 11,36 & 21,24 & 55,53 & 11,87 & 12,84 & 11,52 \\
\hline
\end{tabular}

Keterangan:

$\mathrm{BB}=$ Serbuk batubara

$\mathrm{BS}=$ Serbuk campuran batubara dan sekam padi

$\mathrm{SP}=$ Serbuk sekam padi

Tabel 4. Data hasil pengujian ultimate dan nilai kalor

\begin{tabular}{ccccccccc}
\hline No & $\begin{array}{c}\text { Komposisi } \\
\text { Campuran (\%) }\end{array}$ & $\mathrm{C}$ & $\mathrm{H}$ & $\mathrm{N}$ & $\mathrm{S}$ & $\mathrm{O}$ & $\mathrm{HCV}$ & $\mathrm{LCV}$ \\
& & $(\%)$ & $(\%)$ & $(\%)$ & $(\%)$ & $(\%)$ & $(\mathrm{MJ} / \mathrm{kg})$ & $(\mathrm{MJ} / \mathrm{kg})$ \\
\hline 1 & BB 100 & 41,81 & 6,28 & 0,62 & 0,22 & 43,33 & 16,2 & 15,09 \\
2 & BS 90 & 41 & 5,29 & 0,64 & 0,22 & 43,09 & 16,05 & 14,98 \\
3 & BS 70 & 39,09 & 4,98 & 0,73 & 0,19 & 42,81 & 15,16 & 14,30 \\
4 & BS 50 & 37,28 & 5,89 & 0,83 & 0,16 & 41,26 & 14,89 & 13,39 \\
5 & BS 70 & 35,42 & 5,68 & 0,9 & 0,14 & 40,59 & 13,9 & 12,70 \\
6 & BS 10 & 33,52 & 5,59 & 1 & 0,11 & 39,7 & 13,25 & 11,97 \\
7 & SP 100 & 32,31 & 5,49 & 1 & 0,11 & 39,86 & 12,84 & 11,52 \\
\hline
\end{tabular}

\section{Validasi Hasil Pengujian Sampel dengan Penelitian Sebelumnya}

Berdasarkan hasil penelitan dari beberapa jenis campuran biocoal dibuat perbandingan hasil uji biocoal dengan peneliti peneliti sebelumnya sebagai berikut:

Tabel 5. Perbandingan Analisis Proximate dan Ultimate Batubara

\begin{tabular}{lllll}
\hline Karakteristik & Eksperimen & $\begin{array}{l}\text { Rasheed } \\
(2015)\end{array}$ & Wakuma (2017) & $\begin{array}{l}\text { Assaba } \\
(2017)\end{array}$ \\
\hline Moisture Content & $30,72 \%$ & $12,64 \%$ & $11,00 \%$ & $12,59 \%$ \\
Volatile Matter & $34,68 \%$ & $54,39 \%$ & $30,74 \%$ & $30,73 \%$ \\
Ash Content & $7,74 \%$ & $17,10 \%$ & $19,23 \%$ & $20,92 \%$
\end{tabular}


7 Rio Erlangga Maharja, Syahrul Mubarak, Muhammad Anshar, Jumadi Tangko. Uji Eksperimental Perbandingan Komposisi Sekam Padi dengan Batubara sebagai Bahan Bakar

\begin{tabular}{lllll} 
Fixed Carbon & $26,68 \%$ & $50,63 \%$ & $45,27 \%$ & $46,27 \%$ \\
High Heating Value & $16,2 \mathrm{MJ} / \mathrm{kg}$ & - & $18,62 \mathrm{MJ} / \mathrm{kg}$ & $13,12 \mathrm{MJ} / \mathrm{kg}$ \\
Carbon & $41,81 \%$ & $58,55 \%$ & - & - \\
Hydrogen & $6,28 \%$ & $5,11 \%$ & $3,73 \%$ & $3,37 \%$ \\
Oxygen & $43,33 \%$ & $28,81 \%$ & 8,73 & $8,73 \%$ \\
Nitrogen & $0,62 \%$ & $0,51 \%$ & 1,39 & $1,39 \%$ \\
Sulphur & $0,22 \%$ & $3,67 \%$ & - & - \\
\hline
\end{tabular}

Dari tabel 5 dapat dilihat bahwa jika dibandingkan hasil percobaan analisis proksimat dan ultimat batubara terdapat beberapa nilai yang mendekati, berada pada range dan jauh dari penelitian sebelumnya yaitu sebagai berikut:

Mousture Content (MC) memiliki nilai 30,72\% dan jauh dari tiga penelitian sebelumnya yaitu $12,64 \%, 11,00 \%$ dan $12,59 \%$ hal ini disebabkan karena pengeringan yang dilakukan tidak optimal saat pembuatan sampel. Volatile Matter (VM) memiliki nilai 34,68\% dapat dikatakan akurat karena berada pada range peneletian sebeleumnyayaitu 30,74\%, 54,39\% dan 30,73\%. Ash Content (AC) memiliki nilai $7,74 \%$ dan jauh dari tiga penelitian sebelumnya yaitu $17,10 \%, 19,23 \%$ dan $20,92 \%$. Fixed Carbon (FC) memiliki nilai $26,68 \%$ jauh dari tiga penelitian sebelumnya yaitu 50,63\%, 45,27\% dan 46,27\%. High heating Value atau nilai kalor memiliki nilai $16,2 \mathrm{MJ} / \mathrm{kg}$ dapat dikatakan akurat karena berada pada range penelitian sebelumnya yaitu $18,62 \mathrm{MJ} / \mathrm{kg}$ dan $13,12 \mathrm{MJ} / \mathrm{kg}$.Carbon (C) memiliki nilai $41,81 \%$ mendekati nilai dari penelitian sebelumnya $58,55 \%$. Oksigen (O) memiliki nilai $43,33 \%$ dan jauh dari tiga penelitian sebelumnya yaitu $28,81 \%, 8,73$ dan $8,73 \%$. Nitrogen $(\mathrm{N})$ memiliki nilai0,62\% dapat dikatakan akurat karena berada pada range penelitian sebelumnya yaitu $0,51 \%$ dan $1,39 \%$. Sulphur (S) memiliki nilai 0,22\% dan jauh dari penelitian sebelumnya yaitu 3,67\%.

Tabel 6. Perbandingan Analisis Proximate dan Ultimate Sekam Padi

\begin{tabular}{lllll}
\hline Karakteristik & Eksperimen & $\begin{array}{l}\text { Prega } \\
(2004)\end{array}$ & Anshar (2017) & $\begin{array}{l}\text { Said } \\
(2014)\end{array}$ \\
\hline Moisture Content & $11,36 \%$ & $8,84 \%$ & $10,46 \%$ & $9,00 \%$ \\
Volatile Matter & $55,53 \%$ & $57,95 \%$ & $58,65 \%$ & $56,20 \%$ \\
Ash Content & $21,24 \%$ & $15,24 \%$ & $19,11 \%$ & $22,20 \%$ \\
Fixed Carbon & $11,87 \%$ & $18,64 \%$ & $14,81 \%$ & $12,60 \%$ \\
High Heating Value & $12,84 \mathrm{MJ} / \mathrm{kg}$ & $11,72 \mathrm{MJ} / \mathrm{kg}$ & $13,44 \mathrm{MJ} / \mathrm{kg}$ & $13,24 \mathrm{MJ} / \mathrm{kg}$ \\
Carbon & $32,31 \%$ & $31,65 \%$ & $42,21 \%$ & $49,63 \%$ \\
Hydrogen & $5,49 \%$ & $6,21 \%$ & $5,82 \%$ & $5,78 \%$ \\
Oxygen & $39,86 \%$ & 35,08 & $35,81 \%$ & $44,25 \%$ \\
Nitrogen & $1 \%$ & $1,87 \%$ & $0,38 \%$ & $0,24 \%$ \\
Sulphur & $0,11 \%$ & $0,04-0,08 \%$ & $0,08 \%$ & - \\
\hline
\end{tabular}

Dari tabel 6 dapat dilihat bahwa jika dibandingkan hasil percobaan analisis proksimat dan ultimate sekam padi terdapat beberapa nilai yang mendekati, berada pada range dan jauh dari penelitian sebelumnya yaitu sebagai berikut: 
Mousture Content (MC) memiliki nilai $11,36 \%$ dapat dikatakan akurat karena mendekati tiga penelitian sebelumnya yaitu 10,46\%, 9,00\% dan 8,84\%. Volatile Matter (VM) memiliki nilai 55,53\% dapat dikatakan akurat karena mendekati nilai peneletian sebeleumnyayaitu 58,65\%, 56,20\% dan $57,95 \%$. Ash Content (AC) memiliki nilai $21,24 \%$ dapat dikatakan akurat karena berada pada range penelitian sebelumnya yaitu 22,20\%, 19,11\% dan 15,24\%. Fixed Carbon (FC) memiliki nilai 26,68\% mendekati nilai penelitian sebelumnya yaitu 12,60\%, 14,81\% dan 18,64\%. High heating Value atau nilai kalor memiliki nilai $12,84 \mathrm{MJ} / \mathrm{kg}$ dapat dikatakan akurat karena berada pada range penelitian sebelumnya yaitu 13,44 MJ/kg, 13,24 MJ/kg dan 11,72 MJ/kg.Carbon (C) memiliki nilai 41,81\% dapat dikatakan akurat karena berada pada range penelitian sebelumnya yaitu $31,65 \%, 42,21 \%$ dan 49,63\%. Oksigen (O) memiliki nilai 39,86\% dapat dikatakan akurat karena berada pada range penelitian sebelumnya yaitu $35,08 \%, 35,81 \%$ dan $44,25 \%$. Nitrogen $(\mathrm{N})$ memiliki nilai $1 \%$ dapat dikatakan akurat karena berada pada range penelitian sebelumnya yaitu $0,38 \%, 0,24$ dan 1,87\% . Sulphur (S) memiliki nilai $0,11 \%$ dan jauh dari penelitian sebelumnya yaitu $0,08 \%$.

\section{IV.KESIMPULAN}

1. Berdasarkan rata-rata produksi padi di Indonesia sebesar $73 \times 10^{6}$ ton maka sekam padi yang dihasilkan sebesar $20 \%$ yaitu sekitar $14.638 \times 10^{3}$ ton, dengan demikian maka daya yang dapat dibangkitkan berdasarkan perhitungan adalah $52.6 \mathrm{GWh}$. Campuran batubara dan sekam padi layak dijadikan sebagai bahan bakar alternatif dengan nilai kalor $16.05 \mathrm{MJ} / \mathrm{kg}$ lebih baik dibandingkan biobriket dari sekam padi dengan nilai kalor $13.442 \mathrm{~kJ} / \mathrm{kg}$ yang telah lazim digunakan sebagai bahan bakar alternatif.

2. Hasil penelitian menunjukkan bahwa pada berbagai variasi campuran sekam padi dan batubara, nilai kalor yang diperoleh untuk 10\%:90\% adalah 16.05 MJ/kg, 30\%:70 adalah $15.16 \mathrm{MJ} / \mathrm{kg}$, 50\%:50\% adalah $14.89 \mathrm{MJ} / \mathrm{kg}, 70 \%: 30 \%$ adalah $13.90 \mathrm{MJ} / \mathrm{kg}, 90 \%: 10 \%$ adalah $13.25 \mathrm{MJ} / \mathrm{kg}$, dimana untuk nilai kalor tertinggi diperoleh pada campuran yang mengandung komposisi serbuk batubara $90 \%$ dengan nilai kalor yaitu $16.05 \mathrm{MJ} / \mathrm{kg}$.

\section{DAFTARPUSTAKA}

[1] Elinur, dkk. 2010. Perkembangan Konsumsi dan Penyediaan Energi dalam Perekonomian Indonesia. Jurnal. (Online), (http://schoolar.google.co.id), diakses 17 januari 2018.

[2] Priyambada, Reza dkk. 2017. Analisis Pertambangan Batubara di Indonesia.

[3] Elfiano, E., Natsir, M., and Indra, D., (2014), Analisa Proksimat Briket Bioarang Campuran Limbah Ampas Tebu Dan Arang Kayu, Seminar Nasional Teknik Mesin Universitas Trisakti, 1-6, Vol.KE14, ISBN:978602-70012-0-6.

[4] Kementerian Energi dan Sumber Daya Mineral Direktorat Jenderal Energi Terbarukan dan Konversi Energi. 2016. Rencana Strategis Ditjen EBTKE 2015-2019. (Online), (http://ebtke.esdm.go.id/post/2016/04/13/1186/rencana.strategis.renstra.ditjen.ebtke.2015-2019) diakses 29 Januari 2018

[5] Badan Pusat Statistik. 2012. Sulawesi Selatan Dalam Angka 2011 . Makassar

[6] Anshar, M., Farid Nasir Ani, and Ab Samen Kader. 2015. Combustion Characteristics Modelling of Rise Husk Fuel for Power Plant in Indonesia. In Applied Mechanics and Material Journal, Vol. 695: 815-819.

[7] Maciejewska A., Veringa H., Sanders J., Peteves S.D.”Co-Firing of Biomass with Coal: Constraints and Role of Biomass Pre-Treatment”.European Commission DG JRG.2006. EUR22461EN.

[8] Kwong, P.C.W., Wang, J.H., Chao, C., Cheung, C.W., Kendall, G.’'Effect of Co-combustion Performance and Pollutant Emissions". The Seventh AsiaPacific International Symposium on Combustion and Energy Utilization.2004.Hong Kong SAR. 